\title{
Tissue lipid profile of rats administered saponin extract from the root of bitter kola
}

\author{
Alli Smith Y. R*, Adanlawo I. G \\ Department of Biochemistry, Faculty of Science, Ekiti State University, Ado Ekiti, Nigeria
}

Email address:

allismithyemisi@yahoo.com (Alli Smith Y. R)

\section{To cite this article:}

Alli Smith Y. R, Adanlawo I. G. Tissue Lipid Profile of Rats Administered Saponin Extract from the Root of Bitter Kola, Advances in Biochemistry. Vol. 1, No. 1, 2013, pp. 1-4. doi: 10.11648/j.ab.20130101.11

\begin{abstract}
The present study was undertaken to investigate the effect of saponin extract from the root of Bitter kola (Garcinia kola) on the lipid profile of albino rats tissues (Liver, Kidney and Heart). Twenty albino rats were divided into 4 groups of 5 rats each. They were given rats mash and water ad libitum for 2 weeks to acclimatize them; they were then subjected to different doses of saponin extract from the root of Garcinia kola. Group I (control) received an equivalent volume of water, group II received $100 \mathrm{mg} / \mathrm{Kg}$ body weight of extract, and group III was given $200 \mathrm{mg} / \mathrm{Kg}$ body weight, while group IV received $400 \mathrm{mg} / \mathrm{Kg}$ body weight of saponin extract orally everyday for 21 days. The serum, heart, liver and kidney were then analysed for Total cholesterol(TC), High density lipoprotein cholesterol (HDL-C), Low density lipoprotein cholesterol (LDL-C) and Triglycerides(TG). Administration of 100, 200 and $400 \mathrm{mg} / \mathrm{kg}$ doses of saponin extract from the root of Garcinia kola led to a significant reduction $(P<05)$ in total cholesterol, LDL cholesterol and Triglyceride levels in the serum, Liver, kidney and heart when compared with the control and a significant increase $(P<05)$ in HDL cholesterol concentration when compared with control. Hyperlipidemia, being an important risk factor for cardiovascular disease, is a serious public health problem in the world. This result suggests a dose dependent hypolipidemic potential of saponin extract from the root of Garcinia kola and could play a cardio protective role.
\end{abstract}

Keywords: Garcinia Kola, Saponin, Lipid Profile, Tissue, Dose Dependent, Hyperlipidemia

\section{Introduction}

Medicinal plants are plants which contain substances that could be used for therapeutic purposes or which are precursors for the synthesis of useful drugs (1). The medicinal value of these plants lies in bioactive phytochemical constituents that produce definite physiological action on the human body (2). The use of herbal medicine has become more prevalent, and the past few decades have witnessed a rapidly increasing demand worldwide.

In recent years, cardiovascular diseases such Atherosclerosis, that are caused as a result of hyperlipidemia elevate mortality percent, and the age of death has reduced, so reducing serum hyperlipidemia is very important; a $1 \%$ reduction in serum cholesterol concentration results in a $2 \%$ reduction in the prevalence of coronary artery diseases (3). It is clearly established that long-term consumption of a high fat diet accelerates the development of Coronary Heart Disease (CHD). Dietary cholesterol can increase the level of serum cholesterol to levels which can place an individual at increased risk for the development or exacerbation of atherosclerosis [3, 4]. Coronary Heart Disease (CHD) increases dramatically as the plasma concentration of LDL cholesterol increases [4]. The approach of reducing dietary cholesterol suffers from two limitations, the first is that cholesterol is present in all animal fats and many people are unwilling to scarify their preferred diet. The second is that the liver and other tissues synthesize cholesterol de novo if the dietary supply is inadequate. Consequently, the development of methods for lowering LDL cholesterol levels has become a major focus of medical research.

In recent years, many synthetic drugs have been used to treat cardiac problems. These drugs produce different side effects, depending on their mechanisms of action which may lead to severe complications. Hence present trend is diverting towards the screening of traditional herbal medicines to treat fatal diseases. [5] demonstrated the hypotensive activity of the flowers of $\mathrm{H}$. rosa-sinensis, this work investigates its possible effect on lipids. Some tradomedicinal preparations have been demonstrated to reduce cholesterol levels [5].

Garcinia kola (Bitter kola), is a species of flowering 
plant in the Clusiaceae or Guttiferae family. It is found in Benin, Cameroon, Democratic Republic of Congo, Ivory Coast, Gabon, Ghana, Liberia, Nigeria, Senegal and Sierra Leone . It is given different names in Nigeria. Its natural habitat is subtropical or tropical moist low land forests. The plant has the popular acronym "wonder plant" among the South-Western Nigeria people because of it importance [1]. Saponins are glycosides with distinctive foaming characteristic. They are widely distributed plant metabolites consisting of a steroidal or a triterpenoid moiety having one or more carbohydrates side chains. Saponins have been reported to possess a wide range of biological activities. This article is aimed at investigating the effect of saponin extracts of roots of Garcinia kola on tissue lipid profile of albino rats.

\section{Materials and Methods}

\subsection{Plant Materials}

The root of Garcinia kola (Bitter kola) was collected from Ayetoro-Ekiti, Ekiti state, Nigeria. The samples were thoroughly examined to ensure that they were diseases free before they were identified by Mr Omotayo Oluwafemi at the Herbarium section of Plant Science and Forestry Department, Ekiti State University, Ado-Ekiti, Nigeria. A voucher specimen was deposited in the Departmental Herbarium. The roots were cut into bits and air-dried at room temperature; the dried roots were then crushed into coarse Powder with a pestle and mortar and further milled into a fine power using an electric grinding machine.

\subsection{Preparation of Saponin Extract}

$100 \mathrm{~g}$ of the ground sample was extracted with $500 \mathrm{ml}$ of petroleum ether $(40-60 \mathrm{oC})$ in a soxhlet extractor for $12 \mathrm{~h}$. The air-dried defatted sample was similarly extracted with methanol $(600 \mathrm{ml})$ for $13 \mathrm{~h}$. The method of [6] was used to purify the saponin from the methanolic extract. This was partitioned between 1:1 (v/v) mixtures of $n$ - butanol and water. After shaking very well and allowing standing, the nbutanol layer was separated as a brownish green layer. The aqueous layer was washed with n-butanol until it became colourless. The pooled butanolic layer was evaporated in vacuo to give a residue which was dissolved in $100 \mathrm{ml}$ of methanol and precipitated by adding a large amount of diethyl ether to obtain a solid crystalline dark brown saponin compound. [7]

\subsection{Animals}

Adult male albino rats (200-220g) were obtained from the Animal House of the University of Ilorin, Kwara State, Nigeria. The choice of male animals for this study was subject to availability of experimental animals at the time of this study. The animals were maintained in a well ventilated room under $12 \mathrm{~h}$ light: $12 \mathrm{~h}$ dark cycle and were acclimatized for 2 weeks before the start of the experiment. Animals were allowed to freely feed on their standard pellet diet and water ad libitum. The authors hereby declare that "Principles of laboratory animal care" (NIH publication No. 85-23, revised 1985) were followed, as well as specific national laws where applicable. All experiments have been examined and approved by the appropriate ethics committee.

\subsection{Treatment of Animals}

Twenty (20) albino rats were divided into 4 groups of 5 rats each and subjected to different dosages of saponin extract viz: group I (control) received an equivalent volume of water, group II, $100 \mathrm{mg} / \mathrm{Kg}$ body weight of extract, group III, $200 \mathrm{mg} / \mathrm{Kg}$ body weight of extract and group IV. $400 \mathrm{mg} / \mathrm{Kg}$ body weight of extract for 3 weeks. Animals were sacrificed after the third week, the liver; heart and kidney were promptly excised and homogenized in a buffer solution.

\subsection{Biochemical Analysis}

The concentrations of Total Cholesterol was determined using the method of [8], HDL-Cholesterol was measured by enzymatic colorimetric methods of [9]. and triglyceride by the fossati method associated with trinder reaction [10].Serum LDL.Cholesterol was calculated according to the Friedewald equation. [11]

\subsection{Statistical Analyses}

Data are mean \pm SD of five determinations. Statistical analysis was done by Analysis of Variance (ANOVA) and Duncan Multiple range test.

\section{Results}

Results of tissue total cholesterol, HDL cholesterol, LDL cholesterol and triglycerides concentration of rats administered saponin extract of Garcinia kola are shown in Tables 1-4. Administration of 100, 200 and $400 \mathrm{mg} / \mathrm{kg}$ doses of saponin extract from the root of Garcinia kola led to a significant reduction in total cholesterol levels in the serum, Liver, kidney and heart when compared with the control (Table 1).

Table 1. Tissue Total Cholesterol levels ( $\mathrm{mg} / \mathrm{dl}$ ) of rats administered saponin extract of the root of Garcinia kola.

\begin{tabular}{|c|c|c|c|}
\hline Group & Serum & Liver & Kidney \\
\hline I. Control & $165.35 \pm 15.06^{\mathrm{a}}$ & $172.50 \pm 5.09^{\mathrm{a}}$ & $152.00 \pm 8.20^{\mathrm{a}} 58.20 \pm 0.71^{\mathrm{a}}$ \\
\hline II.(100mg/Kg) & $77.40 \pm 3.90^{\mathrm{b}}$ & $126.80 \pm 4.12^{b}$ & $123.36 \pm 19.45^{\mathrm{b}} 62.97 \pm 6.17^{\mathrm{b}}$ \\
\hline III. $(200 \mathrm{mg} / \mathrm{kg})$ & $51.60 \pm 2.44^{b}$ & $120.06 \pm 5.78^{b}$ & $108.40 \pm 10.02^{\mathrm{b}} 51.33 \pm 2.42^{\mathrm{b}}$ \\
\hline IV. $(400 \mathrm{mg} / \mathrm{kg})$ & $48.56 \pm 3.85^{b}$ & $127.03 \pm 8.94^{b}$ & $100.10 \pm 8.46^{b} 44.37 \pm 0.71^{b}$ \\
\hline
\end{tabular}

Results are mean of 5 determinations $\pm \mathrm{SD}$. Using Analysis of Variance (ANOVA) and Duncan multiple range 
test,means with different superscript are significantly different at $(\mathrm{P}<05)$.

On the other hand Table 2 shows a significant increase in the HDL cholesterol levels in all the tissues of the rats administered the saponin extract of the root of Garcinia kola when compared with the control values.

Table 2. Tissue HDL Cholesterol levels ( $\mathrm{mg} / \mathrm{dl}$ ) of rats administered saponin extract of the root of Garcinia kola.

\begin{tabular}{|c|c|c|c|c|}
\hline Group & Serum & Liver & Kidney & Heart \\
\hline I. Control & $31.20 \pm 6.40^{\mathrm{a}}$ & $34.65 \pm 4.31^{\mathrm{a}}$ & $\begin{array}{l}21.25 \pm 2.75 \\
\mathrm{a}\end{array}$ & $5.20 \pm 1.22^{\mathrm{a}}$ \\
\hline II.(100mg/Kg) & $34.76 \pm 3.85^{\mathrm{b}}$ & $39.96 \pm 8.07^{b}$ & $37.06 \pm 9.82$ & $2^{\mathrm{b}} 12.07 \pm 1.92^{\mathrm{b}}$ \\
\hline III. (200mg/kg) & $38.43 \pm 2.15^{\mathrm{b}}$ & $54.60 \pm 4.20^{\mathrm{b}}$ & $30.63 \pm 4.38$ & $8^{\mathrm{b}} 12.67 \pm 1.01^{\mathrm{b}}$ \\
\hline IV. $(400 \mathrm{mg} / \mathrm{kg})$ & $40.76 \pm 2.51^{b}$ & $57.36 \pm 7.00^{\mathrm{b}}$ & $\begin{array}{l}34.90 \pm 3.06 \\
\text { b }\end{array}$ & 6 \\
\hline
\end{tabular}

Results are mean of 5 determinations \pm SD. Using Analysis of Variance (ANOVA) and Duncan multiple range test, means with different superscript are significantly different at $(\mathrm{P}<05)$.

At all the dose level, kidney, heart and liver LDL cholesterol levels reduced significantly when compared with the control (Table 3).

Table 3. Tissue LDL Cholesterol levels $(\mathrm{mg} / \mathrm{dl})$ of rats administered saponin extract of the root of Garcinia kola.

\begin{tabular}{|c|c|c|c|}
\hline Group & Serum & Liver & Kidney \\
\hline I. Control & $101.39 \pm 6.29^{\mathrm{a}}$ & $85.34 \pm 1.27^{\mathrm{a}}$ & ${ }_{\mathrm{a}}^{88.23} \pm 13.4325 .92 \pm 2.26^{\mathrm{a}}$ \\
\hline II. $(100 \mathrm{mg} / \mathrm{Kg})$ & $27.37 \pm 1.00^{\mathrm{b}}$ & $41.47 \pm 4.07^{\mathrm{b}}$ & $40.01 \pm 2.36^{\mathrm{b}} 19.74 \pm 4.62^{\mathrm{b}}$ \\
\hline III. $(200 \mathrm{mg} / \mathrm{kg})$ & $3.38 \pm 0.56^{\mathrm{b}}$ & $14.47 \pm 1.15^{\mathrm{b}}$ & $35.33 \pm 1.46^{\mathrm{b}} 10.22 \pm 0.96^{\mathrm{b}}$ \\
\hline IV. $(400 \mathrm{mg} / \mathrm{kg})$ & $0.21 \pm 0.04^{\mathrm{b}}$ & $13.24 \pm 1.00^{\mathrm{b}}$ & $24.75 \pm 3.38^{b} 1.33 \pm 0.23^{b}$ \\
\hline
\end{tabular}

Results are mean of 5 determinations \pm SD. Using Analysis of Variance (ANOVA) and Duncan multiple range test,means with different superscript are significantly different at $(\mathrm{P}<05)$.

Tissue triglycerides levels were not too significantly affected in the liver, kidney and heart as shown in Table 4.

Table 4. Tissue triglyceride concentrations $(\mathrm{mg} / \mathrm{dl})$ of rats administered saponin extract of the root of Garcinia kola.

\begin{tabular}{|c|c|c|c|}
\hline Group & Serum & Kidney & Heart \\
\hline I. Control & $163.80 \pm 31.39^{\mathrm{a}}$ & $262.55 \pm \underset{\text { a }}{51.83212 .60 \pm 12.58}$ & $135.40 \pm 12.59^{\mathrm{a}}$ \\
\hline II. $(100 \mathrm{mg} / \mathrm{Kg})$ & $76.33 \pm 17.75^{\mathrm{b}}$ & $226.87 \pm 31.19^{b} 231.46 \pm 27.02^{b}$ & ${ }^{b} 152.80 \pm 9.85^{b}$ \\
\hline $\begin{array}{l}\text { III. } \\
(200 \mathrm{mg} / \mathrm{kg})\end{array}$ & $52.23 \pm 9.41^{\mathrm{b}}$ & $256.47 \pm 13.54^{\mathrm{a}} 212.23 \pm 13.45^{\mathrm{a}}$ & ${ }^{\mathrm{a}} 142.20 \pm 6.15^{\mathrm{b}}$ \\
\hline
\end{tabular}

\begin{tabular}{|c|c|c|}
\hline $\begin{array}{l}\text { IV. } \\
(400 \mathrm{mg} / \mathrm{kg})\end{array}$ & $37.93 \pm 5.28^{\mathrm{b}}$ & $232.10 \pm 14.68^{\mathrm{b}} 203.76 \pm 8.85^{\mathrm{a}} \quad 130.57 \pm 6.73^{\mathrm{a}}$ \\
\hline
\end{tabular}

Results are mean of 5 determinations \pm SD. Using Analysis of Variance (ANOVA) and Duncan multiple range test,means with different superscript are significantly different at $(\mathrm{P}<05)$.

\section{Discussion}

The results of the present study showed significant decrease in the development of hyperlipidemia in the tissues of all the groups treated with saponin extracts of the root of Garcinia kola as serum and the tissue lipid profiles were significantly lowered when compared to control group. The results showed significant decrease in the concentration of TC, LDL Cholesterol and TG; which was similar to the findings of [12]. Indeed, in consistent with our results, the study of [13] indicated that oral treatment with N.sativa oil, decreased serum cholesterol and TG levels by 15.5 and $22 \%$ in normal rats. In another study, N. Sativa oil administration to rats significantly decreased serum TC, LDL Cholesterol and TG and increased HDL Cholesterol [14]. [15], reported a significant decrease in plasma TG and an increase in HDL Cholesterol levels in black seed extract-oral treated rats, compared to the control group.

The increased level of HDL- cholesterol and decreased cholesterol level along with its LDL- fraction, following the administration of the saponin extract could be due to an increased cholesterol excretion and decreased cholesterol absorption through the GIT, or as a result of rapid catabolism of LDL cholesterol by the liver for final elimination in form of bile acids [16]. Hyperlipidemia is characterized by elevated serum total cholesterol and LDL- cholesterol level. Hyperlipidemia associated lipid disorders are considered to cause atherosclerotic cardiovascular disease [17].

\section{Conclusion}

The results from this study have shown that the oral administration of saponin extract from the root of Garcinia kola for 21 days reduced significantly the plasma total cholesterol with its LDL- fraction. Therefore, it may be regarded as a useful therapy for hyperlipidemia and the lowering of circulating cholesterol and the increased in HDLcholesterol by the saponin extract can help prevent coronary atherosclerosis. However, further studies are required to study its effects on hyperlipidemic patients and compare it with lipid lowering drugs.

\section{References}

[1] E. A. Sofowora . Medicinal plant and traditional medicine in Africa. John Wiley and sons LTD. 2008; Pp.1-10.

[2] Akinmoladun, E. O. Ibukun, E. M. Obuotor, and E. O. Farombi. Phytochemical constituent and antitoxidant activity 
of extract from leaves Ocimum gratissimum, Science Research Essay. 2007; Vol. 2:163-166.

[3] Onyeneke E.C, Adebisi KE, Eriyamremu GE, Ojeaburu SI, Asagba SO, Oluba OM . Effect of lipid-based diet on some lipid-metabolizing enzymes. J. Med. Sci.,2007; 7(8): 12831289.

[4] Oluba OM, Adeyemi O, Ojieh GC, Adebisi KE, Isiosio IO, Aboluwoye CO (2008a). Effect of dietary cholesterol on some serum enzymes. J. Med. Sci., 2008; 8(4): 390-394.

[5] Siddiqui, AA., Wani, SM., Rajesh, R. and Alargarsamy R. Phytochemical and pharmacological investigation of Hibiscus rosa sinensis Linn. Indian Journal of pharmaceutical sciences.2006; 68(5):588-593.

[6] Kitagawa, I., Saito, M. And Yoshihawa, M. Structure of soyaponin A, a bisdesmoside of soya sapogenol A from soyabean, the seeds of Glycine max Merril. Chemical and Pharmaceutical Bulletin. 1985; 33: 1069-1072.

[7] Khalil, A.H and El-Adawy, T.A. Isolation, Identification and toxicity of Saponin from different legumes. Food Chemistry. 1994; 50: 197-201.

[8] Richmond, W. Preparation and properties of a cholesterol oxidase from nocardia sp. And its application to the enzymatic assay of total cholesterol in serum.Clin.Chem.1973; 19(12): 1350-1356.

[9] Jacobs, D.S, Kasten, B.L ; De Mott, W.R ; Wolfson, W.L. In laboratory and Test Handbook; Eds ; Lexi-comp Inc: Hudson, Cleveland.1990; p. 219.
[10] Fossati, P., Precipe, L. Serum triglycerides determined colorimetrically with an enzyme that produces hydrogen peroxide. Clin. Chem. 1982; 28: 2007-2080.

[11] Friedewald WT, Levy RRI, Fredrickson DS. Estimation of the concentration of low-density lipoprotein cholesterol in plasma without the use of preparative ultracentrifuge. Clin. Chem.1972; 18: 499 -502.

[12] Ibraheim ZZ. Effect of Nigella sativa seeds and total oil on some blood parameters in female doxorubicin volunteers. Saudi Pharm. J. 2002; 10: 54-59.

[13] Zaoui A, Cherrah Y, Alaoui K, Mahassine N, Amarouch H, Hassar M. Effects of Nigella sativa fixed oil on blood homeostasis in rat. J. Ethnopharmacol. 2002b; 79 (1): 23-6.

[14] El-Dakhakhny M, Mady NI, Halim MA. Nigella sativa L. Oil protects against induced hepatotoxicity and improves serum lipid profile in rats. ARZNEIMITTEL. FORSCH. 2000; 50 (9): 832-6.

[15] Le PM, Benhaddou-Andaloussi A, Elimadi A, Settaf A, Cherrah Y, Haddad PS. The petroleum ether extract of Nigella sativa exerts lipid-lowering and insulin-sensitizing actions in the rat. J. Ethnopharmacol. 2004; 94: 251-9.

[16] Khanna, A.R.F. Rizvi and R. Chander. Lipid lowering activity of phyllanthus niruri in hyperlipidemia rats . J. Ethnoparmacol. 2002; 82: 19-22.

[17] Oyetayo, F.L. Responses of Plasma lipids to edible Mushroom diets in albino rats .Afri. J. Biotechnol 2006; 12631266. 